\title{
Oinarrizko errenta eta ekonomia sozial eta solidarioa
}

\author{
Basic income and the social and solidarity economy \\ Ángel Elías Ortega* \\ UPV/EHUko irakasle titularra, Lan Harremanen \\ eta Gizarte Lanaren Fakultateko dekanoa eta Gezki Institutuko kidea
}

\begin{abstract}
Laburpena: Oinarrizko errenta, unibertsala eta baldintzarik gabea, Espainiako Gobernuak onartutako gutxieneko bizi-diru-sarrera berria moduko baldintzadunak diren beste errenta batzuetatik bereiztea eskatzen duen neurria da, batzuetan nahasi egiten baitira. Kontzeptua azaldu ondoren, zer onura ekartzen dituen azalduko dut; izan ere, berez, kontzeptu gisa, pobrezia-egoerekin amaitzeko aukera ematen du; automatikoki, aberastasunaren banaketan dagoen desberdintasuna nabarmen murrizten du; errenta baldintzatu askotan gertatzen den pobreziaren tranpa ezabatzen du; enplegubaldintzak hobetzen laguntzen du; emakumeari autonomia gehiago ematen dio; eta ez ditu hartzaileak estigmatizatzen. Gainera, oinarrizko errenta puri-purian dagoen neurria dela egiaztatzen duten azken albisteetako batzuk jasoko ditut. Ondoren, oinarrizko errenta eta ekonomia sozial eta solidarioa erlazionatuko ditut, enplegua banatzeko beharra azpimarratuz eta oinarrizko errentak ekonomia sozial eta solidarioko enpresak ugaritzen nola lagunduko lukeen azpimarratuz. Ondorio batzuekin amaituko dut, Nazioarteko Konfederazio Sindikalak esandakoarekin bat egiten dudalarik.
\end{abstract}

Hitz gakoak: oinarrizko errenta unibertsala; baldintzarik gabea; pobrezia; desberdintasuna; ekonomia soziala eta solidarioa; enpleguaren banaketa.

\begin{abstract}
The basic income, understood as universal and unconditional, is a measure that requires differentiation from other conditional incomes, such as the new minimum living income approved by the Spanish government, since they are sometimes confused. After explaining its concept, I will explain the benefits it brings, given that in itself, as a concept, it allows for the elimination of situations of poverty; it automatically implies a significant reduction in the inequality of the distribution of wealth; it eliminates the poverty trap, which occurs in many conditional incomes; it favours the improvement of employment conditions; it makes it possible for women to be more autonomous; and, it does not stigmatise the recipients. Furthermore, I will include some of the latest statements that prove that basic income is a measure that is currently in use. Later, I will relate basic income and the social and solidarity economy, stressing the need for a distribution of employment and how basic income would contribute to the proliferation of social and solidarity economy enterprises. I will end with some conclusions, where I endorse what the International Trade Union Confederation has said.
\end{abstract}

\section{Keywords:}

Claves-deskribatzaile alfanumerikoak: A13 Ekonomiak gizarte-balioekin duen harremana; B55 Gizarte Ekonomia; D60 Ongizate orokorraren ekonomia; D63 ekitatea, justizia, desberdintasuna eta beste irizpide eta arau-neurri batzuk; O35 Gizarte Berrikuntza.

* Harremanetan jartzeko/Corresponding author: Ángel Elías Ortega. UPV/EHUko irakasle titularra, Lan Harremanen eta Gizarte Lanaren Fakultateko dekanoa eta Gezki Institutuko kidea - angel.elias@ehu.eus - https://orcid.org/0000-00027927-8835

Nola aipatu/How to cite: Elías Ortega, Ángel (2020). "Oinarrizko errenta eta ekonomia sozial eta solidarioa», GIZAEKOA - Revista Vasca de Economía Social, 17, 225-244. (https://doi.org/10.1387/gizaekoa.22234).

Jasoa: 06/07/2020; onartua: 21/07/2020.

ISSN 1698-7446 - eISSN 2444-3107 / (c) 2020 UPV/EHU

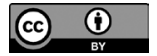

Obra hau Creative Commons Atribución 4.0 Internacional-en

lizentziapean dago 


\section{Oinarrizko errentaren kontzeptua}

Basic Income Earth Network (BIEN) erakundeak onartutako kontzeptuari jarraituz (oinarrizko errenta ezartzearen alde lan egiten duen nazioarteko sarea, aurrerantzean OE), Monterreyko Giza Eskubide Berrien Adierazpen Unibertsalaren (2007) 1.3 artikuluan honako hau adierazten da: " Oinarrizko errenta edo herritarren diru-sarrera unibertsalerako eskubidea, pertsona orori bermatzen zaion eskubidea da, haren adina, sexua eta sexuorientazioa edozein izanda ere. Baldintza material egokietan bizitzeko eskubidea da. Horretarako, zerga-erreformen bidez eta Estatuko aurrekontuen kontura ordainduko diren baldintzarik gabeko aldizkako diru-sarrera jasotzeko eskubidea aitortzen zaio, herritartasun-eskubide gisa, gizarteko kide egoiliar orori, haren beste errenta-iturriak edozein direla ere, bere oinarrizko beharrak betetzeko egokia izan dadin.»

Beraz, BIEN-ek dioen bezala (2006), OE, eskudirutan egindako aldizkako ordainketa da, eta baldintzarik gabe ematen zaie pertsona guztiei, baliabideak edo lana frogatu beharrik gabe. Hauek dira bere bost ezaugarriak:

1. Periodikoa: denbora-tarte erregularretan ordaintzen da (adibidez, hilero), ez diru-laguntza bakar gisa.

2. Eskudirutan ordaintzea: trukerako bitarteko egoki batean ordaintzen da, eta, horri esker, jasotzen dutenek erabaki dezakete zertan gastatzen duten. Beraz, ez da gauzetan (hala nola elikagaietan edo zerbitzuetan) edo erabilera espezifiko baterako kupoietan ordaintzen.

3. Banakakoa: banakakoari ordaintzen zaio, eta ez beste inola, hala nola famili unitateari.

4. Unibertsala: guztiei ordaintzen zaie, baliabideen frogarik gabe.

5. Baldintzarik gabea: ordainketa ez du lan egiteak edo lan egiteko borondateak baldintzatuko.

Azken bi ezaugarri horiek bereizten dute baldintzapeko laguntzetatik, hala nola onartu berri den Gutxieneko Bizitzeko gutxieneko Diru-sarrera edo Euskadin dagoen Diru-sarrerak Bermatzeko Errenta.

\section{Oinarrizko errentak gizartean dituen onurak}

Sarritan esaten da OEk ez duela eraginkortasuna frogatzen duen aurrekaririk, baina, egia esan behar bada, duela ia bost hamarkada egon zen esperientzia bat. Mila familiek, Kanadako Winnipegetik ipar-mendebaldera dagoen Dauphineko 13.000 biztanleko populazioak eta Mincomeko 
biztanleriaren \% 30aren baliokidea denak, 1973tik aurrera 4 urtez kobratu zuten baldintzarik gabeko errenta bat, kide kopuruaren arabera zenbateko aldakorrekoa izan zena eta Forget ikertzaileak (2013) frogatu duen bezala, arrakasta handia lortu zuena. Osasunak hobera egin zuen: ospitaleratzeak \% 8,5era murriztu ziren, eta etxeko indarkeria eta nahasmenduak murriztu ziren. Agian ezagunagoa da duela bost hamarkadatik hona Alaskan dagoen dibidendu banaketa, baina Bregmanek (2017, 28-31 orr.) dionaren arabera arrakasta bermatzen duten esperientziak ugaldu egin dira mundu osoan. Adibidez, Kenyako mendebaldeko eremu pobretu batean, Givedirectly erakundeak frogatu du diru-sarrerak etengabe hazi zirela \% 38raino, etxebizitzak eta abereak erostea bultzatu zela \% 58raino, eta \% 42 murriztu zela haurrek gosea igarotzen zuten egun kopurua; gainera, dohaintza bakoitzaren \% 93 esku dirutan eman zitzaien hartzaileei. 2008an, Ugandako Gobernuak 16 eta 35 urte bitarteko 12.000 laguni $400 \$$ banatu zizkien, negozio-plan bat aurkezteko eskatuz. Bost urte geroago, ondorioak oso positiboak izan ziren, eta beren hezkuntzan eta negozio-ekimenetan inbertitu zuten. Horri esker, diru-sarrerak \% 50 igo ziren, eta kontratatuak izateko aukerak \% 60 baino gehiago handitu ziren. Ugandako beste programa batek $150 \$$ banatu zituen herrialdearen iparraldean 1.800 emakume baino gehiagori, eta, horrela, diru-sarrerak bikoiztu ahal izan zituzten. Beste esperientzia batzuen arabera, korrelazioa dago baldintzarik gabeko ordainketa ekonomikoaren eta delinkuentziaren murrizketaren, haurren hilkortasunaren, desnutrizioaren, nerabeen haurdunaldien, eskola-absentismoaren, errendimendu akademikoaren, hazkunde ekonomikoaren eta sexuen arteko berdintasunaren artean. Namibian, desnutrizioa \% 42tik \% 10era jaitsi zen, eskola-absentismoa \% 40tik $\%$ 0ra, eta delinkuentzia \% 42 murriztu zen. Malauin, neskak eta emakumeak \% 40 gehiago joan ziren eskolara. 2010ean, 110 milioi familiek jaso zituzten baldintzarik gabeko laguntzak Hegoaldeko 45 herrialdetan. Gainera, azken urteotan zenbait proiektu pilotu aplikatu dira, nolabait OEren antzekoak izan daitezkeenak, eta horietako batzuk aipa daitezke (Nazioarteko Sindikatu Konfederazioa, 2018):

-Ontarion (Kanada), 2018ra arte, 4.000 helduri, ezkongabeei 16.989 KAD urtean eta bikoteei 24.027 KAD urtean, banaturiko OE batekin esperimentatu zen. Enplegua izanez gero, diru-sarreraren \% 50 deskontatzen zitzaien.

— Herbeheretako hainbat udalerrik $960 €$-ko zenbateko finkoa ematen diete hilean, inolako lan-betebeharrik gabe, finantza-laguntza behar duten 250 egoiliarri. Onuradunen diru-sarrerek baldintzatzen badute ere, lanari lotuta ez egotean, OEren antzekoa da diru sarrera hau. 
—Finlandian 2015ean egindako esperimentuaren emaitzak aurkeztu ziren: lanik gabeko 2.000 pertsona aukeratu ziren ausaz, bi urtez hilean 560 euroko diru-sarrerak jasotzeko. Gizarte Segurantzaren diru-sarreraz gain, langabezia-laguntzaren zati bat jasotzen jarraitzen zuten, honela, Estatutik jasotzen zituzten diru-sarrerak ez zirelarik erabat baldintzarik gabekoak. Enplegua ez da nabarmen handitu, baina emaitzek egiaztatu dute hobekuntzak eman direla parte-hartzaileen bizitzako zenbait aspektu garrantzitsutan, hala nola, konfiantzan, segurtasunean, osasun mentalean eta fisikoan.

Beraz, programa horien onura nagusiak lau zatitan laburbildu behar dira: lehenik, familiek dirua modu egokian erabiltzen dute; bigarrenik, pobrezia murriztu egiten da; hirugarrenik, iraupen luzeko hainbat onura sortzen dira diru-sarreretan, osasunean eta zergetan; eta, laugarrenik, programa horiek ez dira beste alternatibak bezain garestiak. Gainera, dirua onuradunei zuzenean emanda, funtzionarioen usteak ezabatzen dira, eta ekonomia eta enplegua sustatzen dira.

Bestalde, OE funtsezko neurria da, Nazio Batuen Garapen Jasangarriaren Helburuak betetzearekin bat datorrena, aurrerantzean GJH, 2030 Ekintza Plataformak egiaztatzen duen bezala. Hamazazpi: garapen Jasangarriko Helburuetarako Diziplinarteko Ikerketa (2019) aldizkariaren 1. zenbakia esklusiboki eskaini zitzaion OEri.

Jarraian, OEren birtualtasun batzuk aipatuko ditut labur-labur (Elias eta Rincon, 2017).

\subsection{Pobrezia-egoerekin amaitzen $d a$}

Gizarte-politiken egungo eredua ez da behar bezala funtzionatzen ari. Horren erakusgarri dira 1986az geroztik Eusko Jaurlaritza egiten ari den Pobreziari eta Gizarte Desberdintasunei buruzko Inkestak (2019). Eurostaten diru-sarrera baxuen edo pobrezia erlatiboaren adierazleari dagokionez (diru-sarreren batez bestekoaren \% 60), 2018an 382.316 pertsona izan ziren, hau da, \% 17,7. Pobrezia larriaren adierazlea (medianaren \% 40) 2018an bertan \% 5,1 izan zen, hau da, 109.735 pertsona guztira. 14 urtetik beherako biztanleen artean, haurren pobreziaren eragina \% 10,3koa izan zen 2018an.

Horren aurrean, OE pobreziari modu zuzen eta eraginkorrean aurre egiten dion neurria da, pertsona bakoitzari gutxieneko diru-sarrera egonkorrak ematen baitizkio, beharrak asetzean sortzen diren gastuei aurre egin ahal izateko; horrela, inork ez du pobreziaren mugan bizi behar, eta horrek bizitza bat egitea ahalbidetzen du (Gimeno, 2019). 
Komeni da gogoraraztea Giza Eskubideen Adierazpen Unibertsalaren (aurrerantzean, GEAU) 23. artikuluak «giza duintasunaren araberako existentzia» izateko eskubidea ezartzen duela, 22. artikuluak «pertsona orok bere duintasunerako eta bere nortasunaren garapen askerako ezinbesteko eskubideez gozatzeko duen eskubidea» eta 25. artikuluak «bizitza-maila egokirako eskubidea». Era berean, 1966ko Eskubide Ekonomiko, Sozial eta Kulturalen Nazioarteko Itunak (aurrerantzean, EESKNI) ${ }^{1}$, 7. artikuluan, «Bizi-baldintza duinak» aldarrikatzen ditu, eta 11.1 artikuluan aitortzen du «pertsona orori bere eta bere familiaren bizitza-maila egokia izateko eskubidea, baita elikadura, jantzi eta etxebizitza egokiak izatekoa ere, eta bizi-baldintzak etengabe hobetzeko eskubidea».

Era berean, EESKNIren 2.1 artikuluak, estatu sinatzaileek sinatutakoa betetzeko konpromisoa hartzea eskatzen du, honako hau ezartzen duenean: «Itun honetako estatu alderdi bakoitzak, bai bere aldetik, eta baita nazioarteko laguntza eta lankidetzaren bidez, bereziki ekonomikoak eta teknikoak izango diren neurriak hartzeko konpromisoa hartzen du, eskura dituen baliabideak ahalik eta gehien erabiliz, pixkanaka, bitarteko egoki guztiak erabiliz, neurri legegileak hartzea barne, hemen aitortutako eskubideen erabateko eraginkortasuna emateko».

1989ko Haurren Eskubideei buruzko Konbentzioak 27.1 artikuluan jasotzen denaren arabera, hau berretsi duten estatuek «haur orok bere garapen fisiko, mental eta espiritual, moral eta sozialerako bizi-maila egokia izateko eskubidea» aitortzen dute, eta 27.3 artikuluan, «estatu alderdiak, euren baldintza nazionalen eta bitartekoen arabera, gurasoei laguntzeko beharrezko neurriak hartzera» konprometitzen ditu. eskubide hori eraginkorra izan dadin, guraso nahiz haurren beste arduradun batzuei, behar izanez gero, laguntza materiala eta laguntza-programak ematera konprometituz, batez ere nutrizioari, jantziei lotutakoak. Eta Konbentzio honen 4. artikuluan, era berean, neurri horiek hartzeko betebeharra jasotzen da, xedatu errekurtsoak ahalik eta gehiena izan arte. Izan ere, honela dio: «Estatu alderdiek administrazio-, legegintza- eta bestelako neurri guztiak hartuko dituzte konbentzio honetan aitortutako eskubideei eragingarritasuna emateko. Ekonomia-, gizarte- eta kultura-eskubideei dagokienez, estatu alderdiek neurri horiek hartuko dituzte, dituzten baliabideen maximora arte, eta, beharrezkoa denean, nazioarteko lankidetzaren esparruaren barruan.»

Nire ustez, OE ezartzea botere publikoei eska dakiekeen betebehar juridikoa da. Espainiako Gizarte Laneko Kontseilu Nagusiak (2020) berme-

1 EESKNI funtsezko erreferentea da nazioartean, GEAU garatzen duelako eta Espainiako ordenamendu juridikoaren parte delako, Espainiak berretsi eta 1977ko apirilaren 30eko 103. BOEn argitaratu ondoren. Gainera, Espainiako Konstituzioaren 10.2 artikuluak botere publiko guztiak lotzen ditu giza eskubideen interpretazioan. 
errentei buruzko txostenean (azkena maiatzaren 21ean argitaratu zuen) aipatzen du diru-sarrera hori premiazkoa dela une honetan bizi den babesgabetasun larriko egoera arintzeko. Era berean, defendatzen du ezin dela COVID-19tik eratorritako osasun-larrialdira mugatu, diru-sarrerak bermatzeko sistema bat sortu behar baita herritartasun-eskubide gisa, eta programarik onena $\mathrm{OE}$ bat dela.

\subsection{Ea gutxitzen duen desberdintasun-egoera aberastasunaren banaketan}

Ekonomia Lankidetza eta Garapenerako Antolakundeak dioenez, aurrerantzean ELGA, diru-sarreren arteko desberdintasuna, Espainian nahiko altua dena, areagotu egin zen krisialdian zehar, enplegua nabarmen jaitsi eta diru-sarreren arteko aldea handitu hala. Egoera erosoena duten \% $10 \mathrm{ek}$ aberastasun osoaren erdia inguru izaten jarraitzen du, eta gutxi gorabehera, $\% 60$ pobreenek aberastasunaren bosten bat dute. Aberastasuna metatzeko denbora behar denez, diru-sarreren arteko desberdintasunak gora egin berri du, eta horrek, lan-merkatuko joerekin batera, aberastasuna are gehiago pilatzea eragin dezake (ELGA, 2018, 37 or.).

Aberastasunaren banaketan dagoen desberdintasun handi horren aurrean, garrantzitsua da pilatutako aberastasunak eta onura pribatuak pertsona guztien ahaleginarekin lortu izanaren inguruko gogoeta egitea. Mazzucatok (2013) azaldu digu berrikuntza teknologikoa, hainbat hamarkadatan emandako gobernuaren finantzaketaren emaitza izan dela, hau da, gizartearen zergekin. Hala ere, kostuen sozializazio hori etekinen pribatizazioan amaitzen da. Teorian, finantzaketa hori erkidegoari itzultzen zaio sozietateen gaineko zergak ordainduz, baina praktikan ez da horrela, paradisu fiskalek, zergak saihesteak eta enpresei zergak jaisteak saihestu egiten baitute.

Zerga eta transferentzien Espainiako sistemak birbanaketa-gaitasun txikia du, korrelazio esanguratsua baitago desberdintasun-maila handiaren (\% 34, Gini koefizientea) eta diru-bilketa publikoaren maila txikiaren (bpgaren \% 36, EB-15eko txikiena, Irlandan izan ezik) artean. Diru-laguntzetan ere ez da oso eskuzabala, eta hutsune handiak ditu eskaintzen duen estalduran. Era berean, zerbitzu eta ondasunei loturiko laguntzetan egindako gastuak, hala nola osasunean, sendagaietan eta hezkuntzan, murrizketa handiak izan ditu krisiaren azken urteotan, birbanatze-lan handia izan behar baitute.

Horren aurrean, OE aberastasuna birbanatuz finantzatzen da, zergasistema progresiboagoen bidez edo hain aberatsa ez den gehiengo zabala bermatzen eta lehenesten duten politika ekonomikoen bidez. Arcarons, Raventós eta Torrens-ek (2017) egindako azterlanetan, biztanleria- 
ren \% 20 aberatsenak \% 1a galduko lukeela frogatzen da, eta gainerako \% 80ak irabaziko lukeela. Lanaren Nazioarteko Erakundeak, aurrerantzean LANEk, adierazi zuen OEren proposamenen ugaritasunak, besteak beste honek dituen onurak, kostuak eta finantzaketa-iturriak egokitzeari, pobrezian eragindako ondorioei, desberdintasunari eta generoari buruzko gaiak hobeto ulertzea eskatzen zuela. Esaten nuenez, OEren proposamen batzuek ekitatea eta justizia soziala sustatzeko potentziala dute, eta beste batzuek ongizatearen galera garbia eragin dezakete. Garrantzitsua da kontu handiz aztertzea gai guztiak, proposatutako neurrien progresibotasuna edo erregresibotasuna, irabazleak eta galtzaileak, eta egon daitezkeen arriskuak eta konpentsazioak. Beti saihestu behar dira atzerakoiak diren edo garapen inklusiboa arriskuan jartzen duten neurriak. LANEk, gobernuei OE Gizarte Babeseko Sisteman txertatzeko modu eraginkor bati buruz arretaz hausnartu beharko luketela proposatzen zien, ondo pentsatutako gizarte-aseguru publiko batekin eta gizarte-babeseko beste laguntza batzuekin konbinatuta, eta baita kalitate handiko zerbitzu publikoetarako benetako sarbidea bermatzeko neurri eraginkorrekin ere, hala nola osasuna, hezkuntza, arreta eta beste gizarte-zerbitzu batzuk (Ortiz et al., 2018, 26-30 orr.).

Aldi berean, modu horretan finantzatutako OEk ordezkatzen duen aberastasunaren banaketa hobeak, demokrazia indartzen du; izan ere, gaur egun, munduko \% 0,01 aberatsenak duen eraginak eta botereak desplazatuta dauka herri-subiranotasuna. Raventosek dioen bezala, (2018) gehieneko errenta bat planteatzea, non kopuru jakin batetik aurrera ezin den gehiago irabazi, hau da, \% 100eko zerga-tasa, ez du soilik laguntza publikoak banatzeko eta ahalbidetzeko diru gehiago ematen, baizik eta, aldi berean, aberastasun handiak saihestean, gehiengoaren askatasuna indartzen du.

\subsection{Ea kentzen duen pobreziaren tranpa}

Gaur egungo baldintzapeko sorospen gehienek, baldintza gisa ezartzen dute onuraduna errenta-kopuru jakin batera ez iristea; jasotzen duen soldata-euro bakoitzagatik, jasotako laguntzatik euro bat deskontatuko zaiola esan nahi du. Hala ere, OE baldintzarik gabeko laguntza denez, ez litzateke eurorik deskontatuko edozein enplegu onartzean delarik ere. Desagertu egingo litzateke tranpa horiek sortzen duten motibaziorik eza, eta horrekin batera, egoera horiek sortzen duten ziurgabetasuna lanik gabeko pertsonengan. Aldi berean, enplegua onartzea eta bilatzea oso onuragarriak izango lirateke. 


\subsection{Ea laguntzen duen enplegu-baldintzak hobetzen}

Pertsona askok pairatzen duten prekarietatearen eta lan-ustiapenaren aurrean, OEk askatasun eta erabakitzeko ahalmen handiagoa ematen die langile guztiei. Gaur egun gehiegizko baldintza kaxkarrak dituzten lanpostuak onartu behar dituzten pertsonek boterea irabaziko lukete baldintza horiek onartu edo negoziatzerakoan. Era berean, enplegua ez litzateke diru-sarreren iturri bakarra izango; beraz, bizirauteko betebehar sozial izateari utziko lioke, eta aukera bat izatera pasako litzateke, beste edozein lan mota bezala. Aukera emango luke pertsonen interes nagusia ondo ordaindutako lana aurkitzea izan beharrean benetan motibatzen duen lana bilatzea izatea.

\subsection{Ea autonomia gehiago ematen dion emakumeari}

Gaur egun, emakume asko baldintzatuta sentitzen dira, ekonomikoki bikotekideen diru-sarreren mende daudelako. Horietako batzuk tratu txarreko egoeretan harrapatuta daude, eta ez dute irteteko gaitasunik, neurri batean beren egoera ekonomikoa dela eta. Argi dago OE batek ez duela gizarte honen kultura matxista eta patriarkalaren amaiera ekarriko, baina babes handia da, egoera horiek pairatzen dituzten emakumeei emango liekeen autonomiari esker (Carrero eta Navas-Parejo, 2019, 37-42 orr.).

\subsection{Ea ez dituen hartzaileak estigmatizatzen}

Baldintzapeko sorospenak kobratzeak estigmatizazio argia dakar. Gehien sufritzen duen taldeetako bat etorkinena da. Etorkinek errenta horiek jasotzen dituztela aprobetxatzen da haien eraginkortasunik eza justifikatzeko, eta horrek kolektibo horiekiko diskriminazioa eta gaitzespena eragiten du. Borroka feministaren kasuan bezala, horrelako jarduera xenofoboak indargabetzea ez da OE baten funtsezko puntua, baina atzerritarrekiko sortzen diren estereotipoetako batzuk arintzea ahalbidetzen du.

Atal hau amaitzeko, Bregmanek dioen bezala (2017, 37-39 orr.), dauden aurreiritzi jakin batzuen aurrean, azpimarratu behar da OE ez dela alferrikakoa, pobrezia desagerraraztea baitakar berekin, eta haren izaera unibertsalak herritarrek askoz gehiago babestea ahalbidetzen du. Hori ere ez da arriskutsua, jendeak lan egiteko joera baitaukagu, eta baldintzarik gabeko laguntza denez, ez du motibaziorik kentzen lanagatik diru-sarrerak lortzerako orduan. Maltzurra izan beharrean, egungo kontrol sozialeko sistemak sortzen duen umilazioa saihesten du, eta aberastasuna hobeto birbanatzea eta gobernuaren esku-hartze mugatuagoa ahalbidetzen du. 


\section{Oinarrizko Errentaren gaurkotasuna}

Joan den 2020ko maiatzean, kultura-sektoreko mila profesionalek baino gehiagok (Kulturan lan egiten duen taldea, 2020) manifestu bat sinatu zuten, $\mathrm{OE}$ ahalik eta kultura-politikarik onena dela defendatzeko. Diotenez, OE batek pertsonen bizitza, oro har, eta praktika artistiko eta kulturalen baldintzak konkretuki, hobetu egingo lituzke, eta kulturarako edo beste sektore baterako bestelako errenta-mota baten aurkakoak izango lirateke. Manifestuan sektore horrek pairatzen duen prekarietatea azaltzen zuten; izan ere, langile askok eta askok urtean 6.000 euro ere ez dituzte kobratzen, eta lanak baldintza txarretan egiten dituzte. OEk autonomia, erabakitzeko askatasuna eta negoziatzeko gaitasun handiagoa ekarriko luke, bai kulturaren sektorean, eta baita beste batzuetan ere.

Manifestuan, kulturak duen funtzioaren ideia ere adierazten zuten, gizarteak bizi-baldintza onak ez baditu, hau kontsumitzera iristea ezinezkoa dela ulertuta; bestela, talde elitistenek soilik kontsumituko lukete. Halaber, $\mathrm{OE}$ ez dela panazea bat adierazi zuten, eta beste neurri batzuekin batera funtzionatu behar duela, eta ez dela inola ere horretaz baliatu behar beste baliabide sozial batzuk ezabatzeko. Laburbilduz, OE bat ezarri behar dela uste zuten, honela arrazoituz: "Zuzenean laguntzen die behar duten pertsonei, eta ez du arreta galtzen egituretan, hainbeste finantzaketa-sistema publikok egiten duten bezala, ustez goitik behera doan baina inoiz behera iristen ez den aberastasun-fluxu batean galtzen baitira, non desberdintasunak hainbeste aldiz finkatzen diren eta gutxien behar dutenei mesede egiten zaien».

Era berean, ekainaren 25ean, LGBTI kolektiboek (2020) Oinarrizko Errenta Unibertsalaren aldeko Manifestu bat onartu zuten, eta bertan adierazi zuten izateko eta existitzeko eskubidea zutela. Emantzipatu ezin direnez, errespetatzen ez diren etxe batean bizi behar duten gazteen egoera salatzen zuten, edo LGBTI adingabeena, familia LGBTIfobikoekin konfinamendua igaro behar izan baitute, eta, orain, Gutxieneko Bizi Diru-sarrerak dituen neurrietatik kanpo geratzen baitira. Hori dela eta, "Oinarrizko beharrak aseta izatea bermatzeko» eskatu dute. "Gureak ez ezik, herritar guztienak ere bai, emakumeentzat, adingabeentzat eta gizarte-kolektiboentzat bereziki eskuragarri bihurtuz. Mugimendu feministako kideek aldarrikatu duten genero-ikuspegi garbiarekin, bizitzari eusteko beharrezkoa dena bermatuko duena, gure bizitzak egiten jarraitu ahal izateko denbora libratuko diguna, eta indibiduala, unibertsala eta baldintzarik gabea izango dena. Neurri horren premiazko inplementazioak, sabaia eta elikagaia bermatzeaz gain, LGBTIfobiak eragindako lan-diskriminazio egoerekin amaitzeko aukera ere bermatuko liguke, baita familia-eremuko indarkeria-egoeretatik edo bikotearen barruko indarkeria-egoeretatik irteteko aukera ere, 
eta gehiegikeriazko lan-baldintza prekarioak edo iraingarriak jasan beharrik ez izatea, ekonomikoki eta sozialki kaleratzeko edo baztertzeko beldurrez. Ez dago harrotasunik lehertuta bagaude.»

Halaber, Espainian gizarte eta hezkuntza-arloko 650 profesionalek baino gehiagok Oinarrizko Errenta Unibertsalaren aldeko Manifestua sinatu zuten azken ekainean (2020), sinetsita baitzeuden OE, baldintzarik gabeko diru-esleipen bat, ezinbesteko eta beharrezko politika dela pertsonek bizitza material duina izateko eskubidea bermatzeko. Era berean, Gizarte Zerbitzuen eta Gizarte eta Hezkuntza Zerbitzuen politikak errotik birplanteatzearen aldeko apustua egiten zuten. Manifestuan ondoz ondoko ataletan planteatzen zuten OE: utopiatik errealitatera; gizartea eta herritartasun-eskubideak errotik eta egituran aldatzeko; gizarte- eta komunitatezerbitzuak erabat desberdinak izateko aukera; eta baita OEren beste onura batzuk ere. Manifestua amaitzeko, honako hau esan zuten: «Azken batean, OEk politika publiko bat egitea dakar, bizitzeko eskubidea eta gutxieneko bizi-materialak bermatzeko. Politika horrek, aldi berean, bizitzako beste dimentsio batzuetan ere aukera asko ematen ditu, non gizarte- eta hezkuntza-arloko esku-hartzearen profesionalok jarduten dugun. "

COVID19 osteko Euskal Herriko Ekonomia Ekologikoaren alde -Akademiako 764 profesionalek (ikertzaile eta irakasleak), beste 3.213 pertsonek eta 191 euskal erakundek, besteak beste ELA, LAB, ESK eta STEILAS sindikatuek edo EH-Bildu eta Elkarrekin Podemos bezalako koalizio politikoek - bultzatutako Manifestuaren helburua Euskal Herrian benetan jasangarria den eredu sozio-ekonomiko baterantz aurrera egiteko oinarri batzuk iradokitzea da, bai krisian murgilduta gauden bitartean baita ondoren ere. Eraldaketa hori bultzatzeko oinarrizko bost ildo estrategiko proposatzen dira. Ondorengo proposamen hauek atzerapenik gabe zehaztu eta aplikatu beharko lirateke, osasun krisiaren ostean norabide jasangarriago bat finkatzeko asmoz. Eta, zehazki, bigarren jarduera-ildoan honako hau adierazten da: «Erakunde publikoek muga ekologikoak kontuan hartzen dituzten ekoizpen-, inbertsio- eta kontsumo-politikak sustatzea, eta etorkizuneko belaunaldientzat zor bidegabe eta onartezina saihestea. Era berean, Oinarrizko Errenta Unibertsala bitarteko, pertsonak zentroan jartzen dituen zainketa-sistema bat garatu behar da, gure zaurgarritasuna eta elkarrekiko mendekotasuna onartuta.» Orain dela gutxi idatzi nuen bezala (2020), horrek erakusten du OE ezartzeak babes sozial zabala lortzen duela Euskal Herrian, aspaldi hasitako baina inoiz hain babes zabala lortu ez duen prozesu bat sendotuz. Hogeigarren mendearen amaieran, OEren inguruan eztabaidatu zen Gizarte Eskubideen Gutun baterako Legegintzako Herri Ekimen bat bultzatzearen ondorioz, baina ez zuen hura sartzeko behar zen babesa lortu. Mende honetan, Oinarrizko Errentaren hainbat sinposio egin dira Euskal Herrian, eta 2016ko azaroan Bilbon egindako 
Oinarrizko Errenta Sarearen XVI. Sinposioa baino lehen, inkesta zabal bat egin zen EHUko unibertsitate-komunitatearen artean. Inkesta horrek emandako emaitzen arabera, \% 54,4k babesa eman zion OEri, \% 24,6k, berriz, kontrakoa, eta \% $21 \mathrm{ek}$ ez zuen jarrera argirik agertu. OErekin adostasun handienetik txikienera emandako 3.043 erantzunetatik, 875 (\% 28,8) guztiz ados zeuden, 779 (\% 25,6) nahiko ados, 642 (\% 21,1) ez alde ez kontra, 431 (\% 14,2) kontra eta 316 (\% 10,4) oso kontra. OEren eskaria agerian geratu da, halaber, Kulturaren Euskal Kontseiluaren 2020ko maiatzaren 28ko bilerarako Arte Plastikoen eta Ikusizkoen sektoreak egunotan aurkeztu duen Gutunean, non honako hau adierazten baitzen laugarren puntuan: «Gaur inoiz baino gehiago, sektorearentzat, nahiz eta ez sektorearentzat bakarrik, oinarrizko errenta unibertsal bat ezartzea beharrezkoa da (guztientzat), hainbat eremutatik eskatu den bezala.»

Aurrekoa berretsi egiten da Oinarrizko Errenta Sarearen Elkarteak (2020) 2020ko maiatzaren 12tik 13ra 2.000 pertsonari baino gehiagori egindako inkestaren emaitzekin. Lortutako emaitzen arabera, pertsonen $\% 56$ OEren alde agertzen da. Aitzitik, inkesta erantzun duten pertsonen $\% 30$ baino ez dago neurri horrekin ados.

Espainiako Diputatuen Kongresuko berreraikuntza sozial eta ekonomikorako Batzordeak, 2020ko ekainaren 22an, aditu gisa, Daniel Raventos (2020) ekonomialari eta Espainiako Oinarrizko Errenta Sareko presidenteari agertzeko deia egin zion. Elkarte horrek OEri buruzko azalpen bikaina egin zuen, eta, ondoren, planteatu zitzaizkion galdera guztiei erantzun zien, legebiltzar-talde batzuen berariazko babesa lortuz.

OEri buruz antolatzen ari diren eztabaida eta mintegiak ere asko izaten ari dira. Hurbileko adibide bat da Aberastasunaren banaketa zuzen baten aldeko ToShare Behatokiak (2020) UPV/EHUn antolatu zuen 4 mintegiko zikloa, bertan euskal gazte unibertsitarioek parte haru zutelarik.

\section{Oinarrizko errenta eta ekonomia sozial eta solidarioa}

OE egungo neoliberalismotik urruntzen den politika ekonomiko baten barruan aplikatu beharreko neurria da, eta esparru horretan, garrantzitsuak dira ekonomia sozial eta solidarioaren balioak. 2009ko urrian Johannesburgon,LANEren ekonomia sozialari eta Afrikak munduko krisiari emandako erantzunari buruzko Konferentzian eginiko Ekonomia sozial eta solidarioaren definizioa erabili ohi da: "Ekonomia sozialak [eta solidarioak] enpresak eta erakundeak hartzen ditu barnean, bereziki kooperatibak, mutualitateak, elkarteak, fundazioak eta enpresa sozialak, ondasunak, zerbitzuak eta ezagutzak ekoiztea ezaugarri dutenak, eta, aldi berean, helburu ekonomiko eta sozialak lortu nahi dituztenak, elkartasuna sustatzen dutelarik.» 
LANEren Kooperatiben Sustapenari buruzko Gomendioak, 2002koak (193. zk.), honela definitzen du kooperatiba: «Beren borondatez elkartutako pertsonen elkarte autonomo bat, beren behar eta asmo ekonomiko, sozial eta kulturalak batera asetzeko, baterako jabetzako eta kudeaketa demokratikoko enpresa baten bidez». Gobernuek kooperatiba iraunkorrak eta demokratikoak sortzeko eta sustatzeko politika eta esparru juridikoa ezarri beharko lukete. Lanaren Nazioarteko Konferentziaren (107. bilera, 2018) VI. Elkarrizketa soziala eta tripartismoa txostenaren 105. atalak honako hau dio: «Lan-harreman erregularrak eta tradizionalak jasaten ari diren higadura ikusita, kooperatibak langileen eta enplegatzaileen erakundeek erabiltzen duten antolaketa alternatibo bat dira. Langileen ordezkagarritasunari laguntzen diote, batez ere ekonomia informalean nahiz antolatzeko bestelako modu gutxi dauden eremuetan lan egiten dutenei. Langile independenteentzat eta plataforma digitalen ekonomiarentzat aukera bat plataformen kooperatibismoa da. Adibidez, gero eta taxilari-kooperatiba gehiagok erabiltzen dute metodo hori taximetro-enpresen bitartekaritza ezabatzeko, eta horietako batzuek ukatu egiten dizkiete beren eskubideak eta laguntzak gidariei.»

Kooperatiben printzipioak honako hauek dira: borondatezko batasun irekia, bazkideen koordinazioa, hezkuntza, autonomia eta independentzia, bazkideen parte-hartzea, prestakuntza eta informazioa, komunitatearekiko interesa eta kooperatiben arteko lankidetza (Ruedas, 2016). Hurbileko adibide bat Koopfabrika ${ }^{2}$ da, gizarte-ekonomia berria eta elkarlanean egindako ekarpena sustatzeko programa. 2017an sortu zen, proiektu profesionalak eta ekimen sozioekonomikoak ikuspegi kooperatibo batetik abiarazteko helburuarekin, eta dagoeneko 50 proiektu baino gehiago sustatu ditu. Gizarte-ekintzailetza kooperatiboa komunitatetik sortzen da eta harekin sarea osatzen du; eredu demokratikoa da, autosorkuntzan oinarritua, eta, bideragarritasunetik harago, proiektuaren jasangarritasuna ere jasotzen $\mathrm{du}$, alderdi guztietan.

Gizarte-ekonomia ekonomiaren eta herritarren arteko hurbiltasunean oinarritzen da. Hurbiltasun hori desagertua dirudi azken urteotan, botere ekonomikoek eta herritarrek lapurtu izan balute bezala, gure inguruan gertatzen diren erabaki ekonomikoei zer esanik eta ekarpenik egingo ez bagenie bezala. Hala, gizarte-ekonomiak inplikaziora gonbidatzen du eta partaidetzaren bidez, lotura estua sortzen du ekonomiaren eta gizarte zibilaren artean (Michelsen, 1992).

Gizarte-ekonomiak pentsamendu liberalean dagoen atomizazioari aurre egin behar dio, eta komunitarismoan oinarritutako erakunde-esperien-

\footnotetext{
2 Xehetasun gehiago http://koopfabrika.eus/webgunean
} 
tzia batzuekin identifikatzen da (França Filho, 2002), (França eta Dzimira, 2000), eta helburuetako bat «kideei edo kolektibitateari onura baino lehen zerbitzua ematea da» (Ciriec, 2000).

Era berean, Ekonomia Solidarioaren Gutunak (Ekonomia alternatibo eta solidarioaren Sarea-EASS, 2011) bizitzeko modu bat dela dio, pertsonen integraltasuna barne hartzen duena eta ekonomia bere benetako helburuaren mende jartzea eragiten duena: gizakiaren garapen pertsonal, sozialarentzat eta ingurumenaren sostengarritasunarentzat oinarri materialak modu iraunkorrean hornitzea. Berdintasunaren, enpleguaren, ingurumenaren, lankidetzaren, irabazi-asmorik ezaren eta ingurunearen printzipioetan oinarritzen da. Eta bere misioa garatzeko, zeharkako ardatz hauek ditu:

- Autonomia, askatasun- eta erantzunkidetasun-printzipio gisa.

- Autokudeaketa, aukerak errespetatzen, inplikatzen, hezten, berdintzen eta ahalduntzea ahalbidetzen duen metodologia gisa.

- Kultura askatzailea, pentsamendu sortzaile, zientifiko eta alternatiboen oinarri gisa, elkarrekin bizitzeko, ekoizteko, gozatzeko, kontsumitzeko eta politika eta ekonomia pertsona guztien zerbitzura antolatzeko modu berriak bilatzen, ikertzen eta aurkitzen lagunduko digutenak.

- Pertsonen garapena, dimentsio eta gaitasun guztietan: fisikoak, psikikoak, espiritualak, estetikoak, artistikoak, sentikorrak, harremanak naturarekin harmonian, edozein hazkunde desorekatu ekonomiko, finantzario, beliko, kontsumista, transgeniko eta anomaloren gainetik, "Fikziozko" garapen baten izenean aldarrikatzen ari dena.

- Naturarekin bat egitea.

— Giza elkartasuna eta elkartasun ekonomikoa, gure tokiko, estatuko eta nazioarteko harremanen printzipio gisa.

Estatu eredu berri bat eraiki behar da, herritar guztien existentzia materialerako eskubidea bermatzeko. Estatu bat non ordaindutako lan soila ez den pertsonei duintasuna ematen diena, baizik eta existentzia material bermatua, existitze hutsagatik, pertsona horiek duin bihurtzen dituena. Estatu bat, non Gizarte Segurantzak eskaintzen duen gizarte-babesa, bateragarria izango den herritar guztien existentzia materiala bermatuko duen OE batekin, eta non gizarte-ekonomiak leku handia izango duen, herritar bakoitzaren lehentasunak kapitalaren gainetik ezartzea ahalbidetuz.

Hori dela eta, Bollainek (2016) ondorioztatzen du desberdinak izanik «gizarte-ekonomia eta baldintzarik gabeko oinarrizko errenta osagarriak direla, oro har duten irismen handiagoagatik; horrela, gizarte justuago baterantz joko da, honako hauetan oinarrituta: baldintza materialen 
maximuma, dagoen deshumanizazioaren desagerpena eta herritarrak ekonomiako eragileen helburuen definizioan eta kudeaketan inplikatu ahal izatea, existentziarako eskubidea errealitate izan dadin, duintasunez bizitzeko soilik norberaren esku baino ez egotea.»

Jarraian, ekonomia sozial eta solidarioaren eta OEren arteko erlazio horren bi eremu garrantzitsu jorratuko ditut, hala nola enplegua lanaldia murriztuz banatzea eta OEk ekonomia sozial eta solidarioko enpresei emango liekeen bultzada.

\subsection{Enplegua banatzeko beharra}

Enplegua eta lana ez dira gauza bera. Raventos eta Warkek (2016) honela definitzen dute lana: "Ordaindutako edo ordaindu gabeko jardueren multzoa, horien emaitzek gure espezieko kideei ondasunak eta zerbitzuak ematen dizkietelako eta ugaltzeko balio dutelako»; enplegua, berriz, kontra-prestazio ekonomikoa duten jardueretara mugatzen da. Beraz, lanaren eta enpleguaren arteko alde nagusia, esfera publiko edo formalaren (non produkzio-lana kokatzen den) eta esfera pribatu edo informalaren (non ugalketa-lana kokatzen den) arteko bereizketa handia da.

Enplegua balioesteko funtsezko faktorea astean edo urtean lan egindako ordu-kopurua da. Lan egiteko bizitzea beharrean, bizi ahal izateko lan egitea ahalbidetzen duen lanaldiaren aldeko borroka, langile mugimenduarekiko banaezina da (Elias eta Rincon, 2017), hala egiaztatzen baitu urtero, 1886ko Chicagoko hilketaren ondorioz, maiatzaren 1ean ospatzen den Langileen Nazioarteko Egunak. XIX. mendean, helburu hori izan zen langileen aldarrikapenen arrazoi nagusietako bat. Hala ere, 1960. urteaz geroztik, lanaldia egunean 8 ordukoa eta astean 40 ordukoa da, eta ez dator bat aldi horretan eman den ekoizpenaren eta produktibitatearen igoera handiarekin. Aldi horretan, azpimarratzekoa da Frantziaren kasua, non Aubry Legeekin, 1998 eta 2000 urteen artean. 2000ko urtarrilaren 1etik aurrera, lanaldia astean 35 orduko lanaldira murriztu behar izan duten enpresa guztietan. Frantziako Asanblada Nazionaleko Ikerketa Batzordearen 2014ko txosten batek erakusten du neurri horri esker, 1999 eta 2000 bitartean, Legea enpresa handiei eta sektore publikoari aplikatu zitzaienean, zuzeneko 350.000 lanpostu sortu zirela (De la Fuente eta $\mathrm{Zu}$ biri, 2016).

Bregmanek dioen bezala (2016, 119-141 orr.), ez da Keynes profezia bete, nahiz eta 2000. urtean Frantzia, Herbehereak eta Estatu Batuak 1930ean baino 5 aldiz aberatsagoak izan. Iraultza feminista, emakumearen sarrera masiboarekin, lan-merkatuaren aldaketarako faktore garrantzitsua izan da. Ordaindu gabeko lana barne hartzen bada, Europako eta 
Amerikako Estatu Batuetako emakumeek gizonek baino lan gehiago egiten dute. Holandako biztanleen \% 75, gainezka sentitzen dira denbora faltagatik, laurdenak aparteko orduak egiten dituzte normalean eta zortzitik batek akidura sintomak dituzte. Hala ere, gutxiago lan egiteak estres maila, klima-aldaketa, ezbehar-tasa, langabezia, emakumearen emantzipazioa, biztanleriaren zahartzea eta desberdintasunak hobetzen ditu. Bizimodua ateratzeko zer egin behar dugun galdetu beharrean, geure buruari galdetu beharko genioke nola lortu nahi dugun bizimodua. Lan oro garrantzitsua dela dioen dogma gainditu behar da, eta soldata handiago batek automatikoki balio sozial handiagoko lan bat islatzen duela dioen ideia ukatu baita ere. Behar adina denbora hartzen badugu bakarrik izango gara bizimodu ona kudeatzeko gai, eta, zorionez, hainbat herrialdetan egindako inkestek erakusten dute erosteko ahalmenaren zati bat denbora libre gehiagoz aldatzeko prest gaudela (Skidelsky eta Skidelsky, 2012, 29-30 orr.).

Egoera OE bat izatearen aldekoa da, lanpostuan malgutasun handiagoa izateak segurtasun handiagoa ere izatea eskatzen baitu. Bestalde, enpleguari eusteak lanaldi murritzagoa eskatzen badu, eta enplegua banatzeko aukera ematen badu, OE beharrezko diru-sarrera bihurtzen da soldata osatzeko eta pertsona bakoitzari baliabide ekonomiko egokiak bermatzeko. OE jasotzeak aukera ematen die pertsona guztiei enplegutik eratorritako soldataren mende ez egoteko.

Aukera bat ekonomia sozial eta solidarioko enpresek lan-astea murrizteko konpromisoa har dezatela da, horrela lanpostuak sortzeko aukera emanez. Konpromiso horrekin erreferente on bihurtuko dira herritarrek OErako duten eskubidea lortzeko prozesuan.

\subsection{Oinarrizko errentak ekonomia sozial eta solidarioko enpresak ugaritzen lagunduko luke}

Ikusi dugunez, ekonomia sozial eta solidarioak ekonomiaren eta herritarren arteko hurbiltasuna planteatzen du, bai eta gizakiaren garapen pertsonalerako, sozialerako eta ingurumenerako oinarri materialak modu jasangarrian hornitzeko helburua ere. Hori dela eta, OEak pertsona askok ekonomia sozial eta solidarioko enpresetan sinestea edo haiekin bat egitea erraztuko du, beste batzuekin batera beren proiektuak garatzeko tresna gisa, beren gaitasunak garatuz eta gizarte-beharrak asetzen lagunduz.

Hori izango litzateke, adibidez, kulturaren esparruan mugitzen den pertsona-espektro zabal eta askotarikoaren kasua, baina baita beste askorena ere, OE bat izan ezkero, zentzuzko lanak bilatuko luketena; izan ere, edozein enplegu onartzeko betebeharrik ez dutenez, irekita egongo lirateke beste lankidetza-proiektu batzuei ekiteko edo horiekin bat egiteko. 


\section{Ondorioak}

OE funtsezko neurria da, baina ezin du inoiz politika ekonomiko bat ordezkatu, politika horren zati garrantzitsu bat izan behar baitu. Horregatik, bat nator Nazioarteko Konfederazio Sindikalaren txostenarekin, aurrerantzean NKS (2018), babes sozial integraleko sistema egokien garapena babesten baitu, eta etengabe eskatzen die hauxe gobernuei:

- Lan-baldintza egokiak bermatzea, besteak beste, gutxieneko bizi-soldata egokiak ezarriz, laneko osasun eta segurtasun-neurri egokiak hartuz, zentzuzko lanaldiak ezarriz, enpleguan segurtasuna bermatuz eta askatasun sindikala eta negoziazio kolektiboa errespetatuz - Lanaren nazioarteko arauen ildotik-.

- Gizarte-babes integral egokia ziurtatzea - Gizarte Segurantzari buruzko LANEren 102. hitzarmenean eta gizarte-babeseko pisuei buruzko 202. Gomendioan xedatutakoaren ildotik-, seme-alabengatiko diru-sarreren berme unibertsalak ematea adinekoentzat eta langabezia-kasuan. Oraindik ez dauden herrialdeetan babes sozialeko etxebizitzak ezartzea eskatu dute sindikatuek.

—Langileek enplegua aldatzean gizarte-babeseko eskubideak, hala nola pentsioak, langabezia-laguntzak, prestakuntzarako baimenak eta osasun-asegurua kontserbatu eta eramangarriak izan daitezen sustatzea.

- Hezkuntzan, prestakuntzan eta etengabeko ikaskuntzarako aukeretan inbertitzea, langileen gaitasunak lan-merkatu aldakorrarekin parekatzeko. Kalitatezko ikaskuntzak bultzatu behar dira, eta lana galtzen dutenentzako prestakuntza eta birziklatze-neurri profesionalekin batera finantza-laguntza egokia emango dela ziurtatu behar da, hala nola prestakuntza eta gaikuntza diru-laguntzak.

- Lan-merkatuan aldaketa handiak izan dituzten langileentzako trantsizio justua bermatzea, hala nola automatizazioa, digitalizazioa eta karbono gutxiko ekonomiarako trantsizioa. Horretarako, gobernuek lan-merkatuaren beharrak aztertu behar dituzte eta plangintza egokia egin behar dute, gizarte-solaskideekin lankidetzan arituz, eraldaketa horiei aurre egiteko behar bezala aurrea hartzeko, prestatzeko eta inbertitzeko. Langile horientzako konpentsazio egokia, ahal denean langileak berresleitzeko neurriak, babes sozial unibertsal eta transferigarria, eta etengabeko trebakuntza eta ikaskuntzarako sarbidea.

—Lan-merkatuaren plangintza on baten bidez kalitatezko enplegua lortzea sustatzea, solaskide sozialekin batera, eta, beharrezkoa denean, enplegu-bermeak ezartzea. 
Beraz, NKSk ez du uste saihestezinak direnik langabezia gero eta handiagoa izatea eta enplegu prekarioa, ezta arazo horiei eraginkortasunez aurre egiteko tresna bakarra OE denik ere. Azken baieztapen horri gehitu nahi diot hemen planteatutako OE, ongiak sustatutakoa, ezin hobeto egokitzen dela LANEk eskatutako eskakizunetara, eta neurri hori guztiz osagarria dela kalitatezko enplegua lortzeko.

Ildo horretan, garrantzitsua iruditzen zait 2018ko urtarrilaren 23an Europako Kontseiluaren Parlamentu Batzarrak ebazpen bat onartu izana, non, beste akordio batzuekin batera, bere 47 estatu kideak Oinarrizko Errenta unibertsalak eskubideak eta gizarte-kohesioa lortzeko bidean aurrera egitea ahalbidetzen zuela egiaztatzeko jarduerak sustatzera animatzen baitzituen. Zehazki, Gizarte Gaietarako, Osasunerako eta Garapen Jasangarrirako Batzordearen txostenaren laburpenean, Nunzia Catalfo kontalaria izanik, honako hau dio: "Pobreziarekin eta giza duintasuna etengabe ahultzen duten desberdintasunen igoerarekin, Europako herrialde gehienak guztiontzako bizi-maila duina bermatzeko borrokan ari dira. Oinarrizko diru-sarrera, edo herritartasunekoa, gizarte-segurantzako modu bat da, herritar bakoitzari bizitzeko diru-kopuru erregular bat eman diezaiokeena. Unibertsaltzat, indibidualtzat, baldintzarik gabekotzat eta bizitza duina eta gizartean parte hartzea bermatzeko nahikotzat definituta, erabateko pobrezia arintzen lagunduko luke, eta, aldi berean, lan egiteko pizgarriak kenduko lituzke. Lan ez-estandarrean lan egiten duten eta lana partekatzen duten pertsonen eta azpi-enplegatuen diru-sarrerak osa ditzake. Oinarrizko diru-sarrera bat ezartzeak guztiontzako aukera-berdintasuna bermatu ahal izango luke, gizarte-laguntza, zerbitzu eta programen mosaikoa baino modu eraginkorragoan. Hala ere, gizarte-politika hain goitik behera aldatzeko zailtasun praktikoak direla eta, herrialde bakoitzean sakoneko eztabaida egin behar da etengabe bermatutako diru-sarrera horren modalitateak zehazteko eta herritarren eta Estatuaren arteko gizarte-kontratu berri baten parte gisa finantzatzeko moduak zehazteko. Horrenbestez, txostenean hainbat gomendio egiten zaizkie Estatu kideei, iraganean eta orain egindako ekimenak aztertzeko gonbita luzatzen zaie, hau da, maila guztietako oinarrizko diru-sarrerak bertatik bertara frogatzera eta biztanleriaren kategoria kalteberei ematen zaien laguntza handitzera.»

Amaitzeko, nire ustez, OE ezartzea botere publikoei eska dakiekeen betebehar juridikoa da, eta ekonomia sozial eta solidarioaren ereduari erantzuten dioten enpresek, herritartasun-eskubide gisa ezartzea ahalbidetuko duten baldintzak bultzatu behar dituzte. Horrek, enplegu-lanaldia murrizteko prozesuan aurrera egitea ekarriko du, banaketaren hobekuntza eraginez. Era berean, ekonomia sozial eta solidarioaren eredua zabaltzen eta indartzen lagunduko duen neurria izango da $\mathrm{OE}$. 


\section{Bibliografia}

Aberastasunaren banaketa zuzen baten aldeko ToShare Behatokiak. (2020). Oinarrizko errenta unibertsalak gizartean eta pertsonen bizitzan izango lituzkeen ondorioei buruzko 4 mintegiko zikloa. https://www.ehu.eus/es/web/lanharreman-gizarte-langintza-fakultatea/-/toshare-eventos\#Eventos10 estekan eskuragarri.

Arcarons, J., Raventós, D. eta Torrens, L (2017). Renta básica incondicional. Una propuesta de financiación racional y justa. Barcelona: Del Serbal.

Basic Income Earth Network (2006), Reino Unido. https://basicincome.org/ about-basic-income/ estekan eskuragarri

Bollain, J. (2016). «Renta Básica Incondicional y Economía Social: un intento de relación. REVES, 17534, 46 or., http://www.ehu.eus/ojs/index.php/gezki/ article/download/17534/15539 estekan eskuragarri.

Bregman, R. (2017), Utopia para realistas. A favor de la renta básica universal, la semana laboral de 15 horas y un mundo sin fronteras. Barcelona: Salamandra, 37-39 eta 119-141orr. https://kupdf.net/download/utopia-para-realistasrutger-bregman_59c359ad08bbc577186870d0_pdf estekan eskuragarri.

Carrero, C. eta Navas-Parejo, M. (2019): «Efectos sobre la igualdad y los roles sociales». Diecisiete: Investigación interdisciplinar para los Objetivos de Desarrollo Sostenible. $137-42$ orr.

CIRIEC (2000). Economía Social y empleo en Europa. Valencia: CIRIEC España.

COVID19 osteko Euskal Herriko Ekonomia Ekologikoaren alde Akademiako Profesionalek. (2020). Covid-19 osteko Euskal Herriko Ekonomia Ekologikoaren Manifestua. https://euskalherriapostcovid19.eus/es/inicio/ estekan eskuragarri.

De la Fuente, M. eta Zubiri, J.B., (2016). "Efectos sobre el empleo de la reducción del tiempo de trabajo: aprendizajes de la experiencia francesa». Lan $\mathrm{Ha}$ rremanak, 34, 102 orr. http://www.ehu.eus/ojs/index.php/Lan_Harremanak/ article/view/16558/14750 estekan eskuragarri.

Ekintza 2030 plataforma (2019). «Renta Básica: ¿Hacia el fin de la pobreza?». Diecisiete: Investigación interdisciplinar para los Objetivos de Desarrollo Sostenible, 1, https://plataforma2030.org/images/R17/1/N1_COMPLETA.pdf estekan eskuragarri.

Ekonomia alternatibo eta solidarioaren Sarea. (2011). «Carta de Principios de la Economía Solidaria». http://www.economiasolidaria.org/files/CARTA_ ECONOMIA_SOLIDARIA_REAS.pdf estekan eskuragarri.

Ekonomia Lankidetza eta Garapenerako Antolakundea. (2018). «España, Visión General». Estudios económicos de la OCDE. 37 orr. https://www.oecd.org/ economy/surveys/Spain-2018-OECD-economic-survey-vision-general.pdf estekan eskuragarri.

Elias, A. (2020). «La renta básica en el manifiesto social de Euskal Herria». http:// www.redrentabasica.org/rb/la-renta-basica-en-el-manifiesto-social-de-euskalherria/ estekan eskuragarri. 
Elias, A. eta Rincon, L. (2016). "Algunas virtualidades de la renta básica», Boletín Hegoa, 48, 48-50 orr. http://boletin.hegoa.ehu.es/mail/45 estekan eskuragarri.

Espainiako Gizarte Laneko Kontseilu Nagusiak (2020). Trabajo Social ante la Garantía de Rentas. http://www.cgtrabajosocial.es/app/webroot/files/consejo/ files/emergencias/Trabajo\%20social\%20Garanti\%C3\%ACa $\% 20 \mathrm{de} \% 20$ Rentas\%2021.05.2020\%20(1).pdf estekan eskuragarri.

Eusko Jaurlaritza (2019). Emaitza nagusiak. Gizarte Beharrei buruzko Inkesta 2018. PGDI Pobrezia modulua. Eusko Jaurlaritzako Enplegu eta Gizarte politiketako Sailaren Estatistika Organo Espezifikoa, 9 or.

Forget, E. (2013). The Case for Basic Income in Canada. https://www.researchgate. net/publication/275648949_The_Case_for_Basic_Income_in_Canada estekan eskuragarri.

França Filho, G., eta Dzimira, S. (2000). Don et économie solidaire: esquisse.

França Filho, G.C.D. (2002). Terceiro setor, economia social, economia solidária e economia popular: traçando fronteiras conceituais. Bahia Análise \& Dados, 12 (1), 9-19 orr.

Gimeno, J. (2019). «De rentas mínimas a Renta Básica». Diecisiete: Investigación interdisciplinar para los Objetivos de Desarrollo Sostenible, 1, 65-70 orr. https:// plataforma2030.org/es/rb/de-rentas-minimas-a-renta-basica estekan eskuragarri.

Giza Eskubide Berrien Adierazpen Unibertsala. (2007). Monterrey. https:// www2.world-governance.org/IMG/pdf_DUDHE.pdf estekan eskuragarri.

Gizarte eta hezkuntza-arloko esku-hartzeko profesionalak. (2020). Manifiesto por una Renta Básica Universal, http://www.rendabasicaara.org/ estekan eskuragarri.

Kulturan lan egiten duen taldea. (2020). Manifiesto por una renta básica universal $e$ incondicional. https://nativa.cat/2020/04/gent-que-treballa-en-cultura-peruna-renda-basica-universal-i-incondicional/ estekan eskuragarri.

LGBTI kolektiboak. (2020), Manifiesto por una Renta Básica Universal, https:// lgbtixrbu.wordpress.com/ estekan eskuragarri.

Mazzucato, M. (2014). The Entrepreneurial State: Debunking Public vs. Private Sector Myths, Londres: Anthem.

Michelsen, J. (1992). El mercado, el estado del bienestar y el sector de la economía social. El caso de Dinamarca. J.L. Monzón, y J. Defourny (arg.) Economía social. Entre economía capitalista y economía pública. Valencia: CIRIECEspaña, 227-262 orr.

Nazioarteko Konfederazio Sindikala (2018). Informe de politica económica y social: Renta Básica Universal, 5-6 orr. https://www.ituc-csi.org/IMG/pdf/universal_ basic_income_es.pdf. estekan eskuragarri.

Oinarrizko Errenta Sarearen Elkartea (2020). Nueva encuesta sobre la Renta Básica en el Reino de España, http://www.redrentabasica.org/rb/nueva-encuesta-sobrela-renta-basica-en-espana/ estekan eskuragarri.

Ortiz, I., Behrendt, C., Acuña-Ulate, A. eta Nguyen, Q. (2018). Universal Basic Income proposals in light of ILO standards: Key issues and glo- 
bal costing. Ginebra: LANE. Extension of Social Security. Working Paper, 62. 26-30 orr. https://www.ilo.org/wcmsp5/groups/public/---ed_protect/---soc_ sec/documents/publication/wcms_648602.pdf estekan eskuragarri.

Raventos, D. (2018). «Renta básica y renta máxima». Sin Permiso. http://www. sinpermiso.info/textos/renta-basica-y-renta-maxima estekan eskuragarri.

Raventos, D. (2020). Espainiako Diputatuen Kongresuko Ekonomia eta Gizartea Berreraikitzeko Batzordean esku hartzea. http://www.redrentabasica.org/rb/ intervencion-de-daniel-raventos-en-la-comision-de-reconstruccion-economicay-social/ estekan eskuragarri.

Raventos, D. eta Wark, J. (2016). «Trabajo remunerado, trabajo doméstico, trabajo voluntario y Renta Básica». Sin Permiso. http://www.sinpermiso.info/ textos/trabajo-remunerado-trabajo-domestico-trabajo-voluntario-y-rentabasica estekan eskuragarri.

Ruedas, I. (2016). «Sabes qué es y cómo funciona una cooperativa?». Pyme al día. Skidelsky, R. y Skidelsky E. (2012). How Much is Enough? The Love of Money and the Case for the Good Life. Nueva York: Penguin, 29-30 orr. 